\title{
Incentive Mechanism of Economic Protection of Rocket and Space Industry Enterprises from Risks
}

\author{
Sergei S. Golubev ${ }^{1 *[O R C I D ~ 0000-0001-8745-6235], ~}$ \\ Alexandr S. Mironov 2[ORCID 0000-0002-4106-5519], \\ Alexandr S. Kosarev 2[ORCID 0000-0002-1288-4355]
}

\author{
${ }^{1}$ Moscow Polytechnic University, Moscow, Russia \\ ${ }^{2}$ All-Russia Scientific Research Institute “Center”, Moscow, Russia \\ Sergei.golubev56@mail.ru
}

\begin{abstract}
The paper discusses the development of incentive plans for personnel of enterprises in the rocket and space industry, who takes risks, in view of the results of their activities. Mechanisms for constructing long-term personnel incentive plans taking into account the key indicators of risk assessment of enterprises in the rocket and space industry are proposed. Methods for calculating and implementing a deferral (installment) of bonuses to top management and other employees taking risks have been considered. The risk indicators of enterprises of the rocket and space industry have been determined, and a methodology for their calculation has been proposed. Key indicators for payment/adjustment of deferred bonuses have been proposed. The expediency of expanding the non-monetary part of bonuses to employees of enterprises in the rocket and space industry, for example, in the form of options and shares, has been proved; specific examples of non-monetary incentives for employees of enterprises in other industries have been given. The problems of tax accounting of annual bonuses of key employees holding managerial positions in the organization when calculating income tax have been considered. Recommendations are given on accounting for deferrals at industrial enterprises. The novelty of the approach lies in the authors' proposal to use the incentive mechanisms, tested in the financial sphere, of protection against risks at industrial enterprises of the rocket and space industry as well as when adapting the principles of calculating and paying the deferred bonus to employees of the enterprises in the rocket and space industry, taking into account the risks of rocket launching, arising at these enterprises.
\end{abstract}

Keywords: rocket and space industry, risks, long-term incentive, bonus deferral, company shares

\section{INTRODUCTIONS}

At present, the rocket and space industry (hereinafter - RSI), being competitive in the world market of space services, occupies an important place in the national security system of the country due to its high knowledge-intensity and high production technology, has great innovation capabilities, and determines the country's space potential. At the same time, due to the emerging uncertainties, the complexity of the ongoing production and organizational processes, the RSI is characterized by the presence of high risks of production and operation activities. The RSI is characterized by a fairly high accident rate at the stage of placing expensive spacecraft in orbit.
Table 1 provides statistics on space launches, reflecting the accident rate for 2010-2020 [1]. It should be noted that in Russia the largest share of unsuccessful launches is 1.36, in the People's Republic of China -1.00 , in the USA -0.82 .

The causes for the risks arising in the RSI are many factors of the internal and external environments, among which it is necessary to highlight personnel problems, very strong wear and tear on the equipment used, insufficient funding of space-related programs [2].

The causes, in contrast to the factors, are more specific and it is they that ultimately lead to the emergence of risks. The factors and causes of risks in the RSI are presented in Figure 1. 
Table 1. The number of space launches and their accident rate for 2010-2020

\begin{tabular}{|c|c|c|c|c|c|c|c|c|c|c|c|c|c|}
\hline Countries & $\begin{array}{l}\text { Number of } \\
\text { Launches }\end{array}$ & 울 & స్ & สิ & ลั & จั & ลำ & ำ & సิ & $\frac{\infty}{2}$ & สิ & จิ & 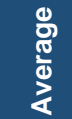 \\
\hline \multirow{2}{*}{ Russia } & total number & 31 & 35 & 29 & 35 & 37 & 29 & 19 & 19 & 17 & 22 & 15 & \\
\hline & number of accidents & 1 & 4 & 1 & 2 & 2 & 2 & 1 & 1 & 1 & 0 & 0 & 1.36 \\
\hline \multirow{2}{*}{ USA } & total number & 15 & 18 & 13 & 19 & 23 & 20 & 23 & 29 & 31 & 21 & 37 & \\
\hline & number of accidents & 0 & 1 & 1 & 0 & 1 & 2 & 1 & 0 & 0 & 0 & 3 & 0.82 \\
\hline \multirow{2}{*}{$\begin{array}{c}\text { People's Republic } \\
\text { of China }\end{array}$} & total number & 15 & 19 & 19 & 15 & 16 & 19 & 22 & 18 & 39 & 34 & 39 & \\
\hline & number of accidents & 0 & 1 & 0 & 1 & 0 & 0 & 1 & 1 & 1 & 2 & 4 & 1.00 \\
\hline
\end{tabular}

Source: [1]

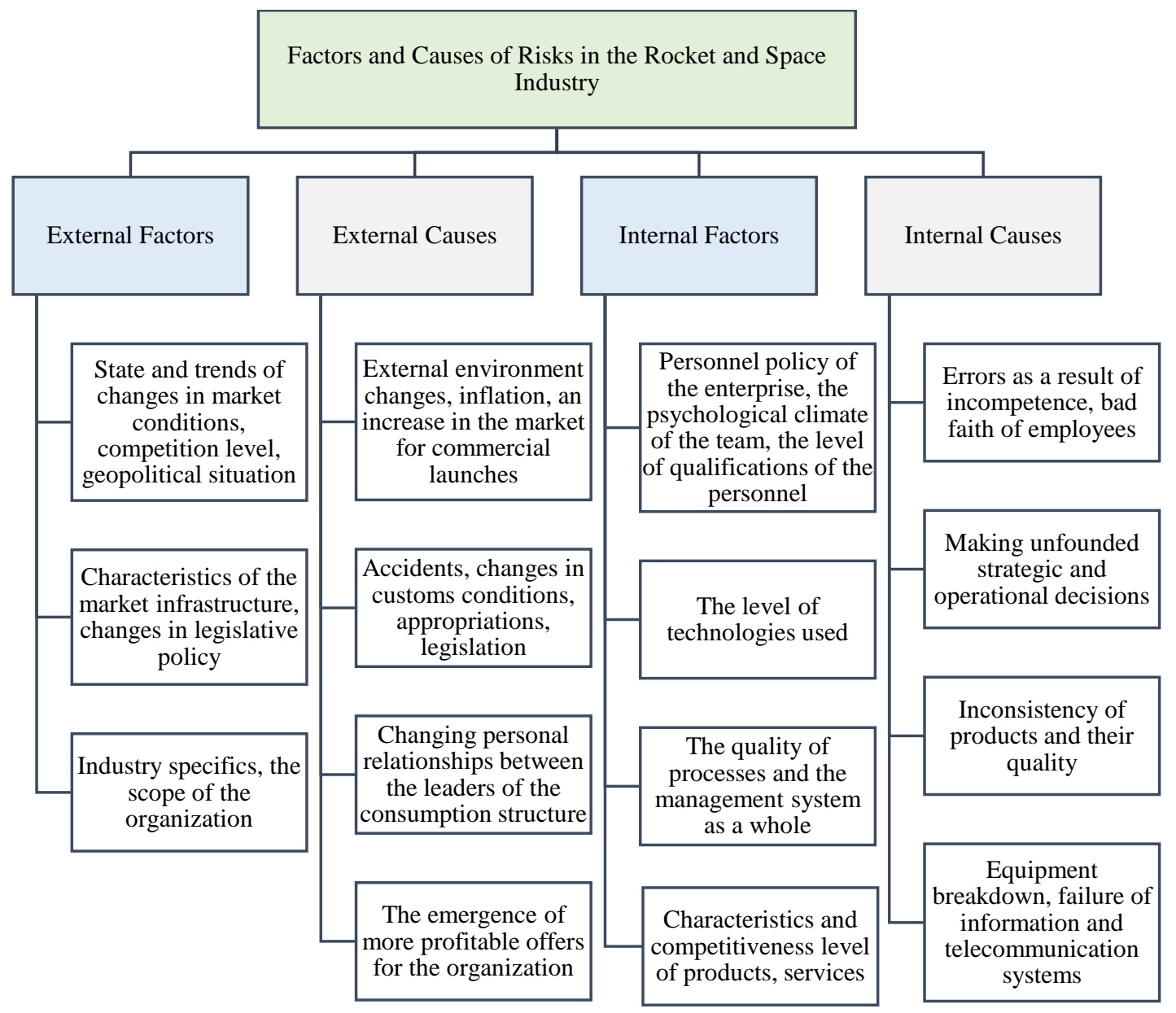

Figure 1. The factors and causes of risks in the RSI Source: Compiled by the authors

Low risks arise in the provision of space services, information processing, and in the operation of ground communication and broadcasting equipment.

The greatest risks arise during the production and operation of launch vehicles (up to $80 \%$ of all risks). This is primarily due to the use of explosive fuels in production, testing, and launching. A feature of the operation of rocket and space equipment is the impossibility of eliminating emerging malfunctions on the ground, which also leads to a sharp increase in the risk of the operation of this equipment.

The analysis carried out by the authors have shown that the causes of emergency situations in most cases are defects made by personnel of the RSI enterprises, as well as low-quality components which are also purchased by the personnel of the enterprise, and low qualification of the personnel. Thus, a person becomes the cause of most emergencies [3, 4]. 
Effective management and production activities of personnel in making management decisions can help to reduce the risks of the RSI activities. Specialists of the RSI enterprises should make more profitable and less risky management decisions by analyzing in-depth all possible alternative decisions. The decisions made should be innovative and contribute to the introduction of modern, more reliable technologies in conjunction with the digitalization of production and organizational processes. It is necessary to stimulate personnel to develop and enrich creative activity, analyze and search for all possible solutions to prevent risks. It is necessary to provide material support for all the employees involved in risky production and organizational activities. Thus, the high probability of accidents in the RSI, as well as the serious nature of their consequences, require the development of new mechanisms aimed at reducing the risk of emergencies during the production and operation of rocket and space technology.

The authors propose a new incentive mechanism for economic protection against high risks, which has justified itself when used in banking activities which are also associated with work in conditions of risk: a mechanism of deferred payment of bonuses, based on the results of actual emergencies (risk situations) during the creation and operation of rocket and space technology $[5,6]$.
Modern requirements for personnel incentive plans significantly change the views on the risks of the organization, as well as their impact on the existing plan of remuneration for the heads of the organization, top managers, and other employees who take risks $[7,8]$.

The design of the remuneration plan for personnel working in conditions of constantly emerging risks is being changed. Bonuses for top managers and personnel encourage highly efficient work, risk reduction, as well as an increase in the profit and results of the enterprise.

\section{MATERIALS AND METHODS}

The methods for conducting this study are based on the adaptation of methods of payment of deferred bonuses in financial institutions operating in risk conditions to enterprises of the RSI which also operate in conditions of constantly emerging risks.

As the analysis of financial organizations' remuneration plans carried out by the authors has shown, the share of short-term incentive plan (hereinafter - STIP) bonuses in the structure of top management's income is large, and long-term results have little effect on the remuneration plan, and as a result, the share of long-term incentive plans (hereinafter - LTIP) is not large (Figure 2) [9].

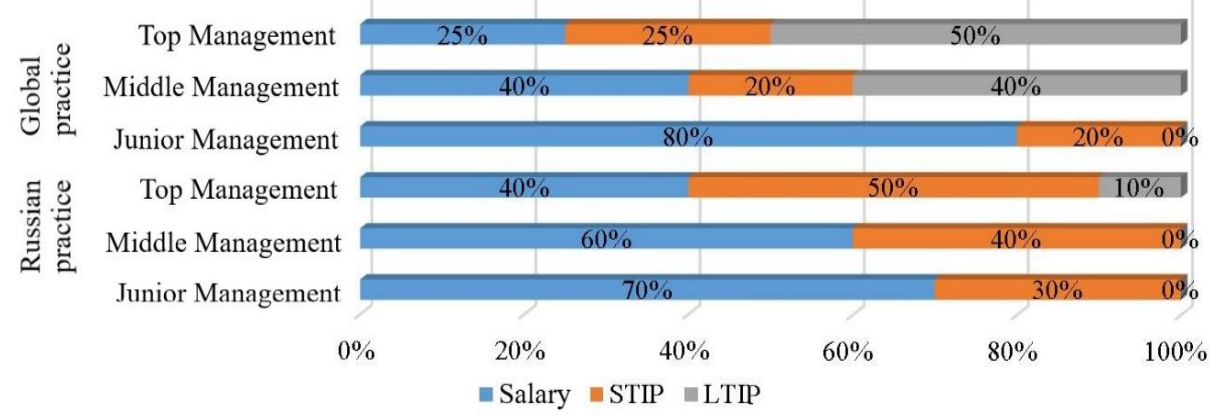

Figure 2. Structure of annual income of top managers in Russia and abroad Source: Compiled by the authors

Let us consider the basic principles of the payment of deferred bonuses, taking into consideration the risks of production activities $[10,11]$ :

- the remuneration plan should take into account current and potential risks;

- the non-fixed part of the bonus should be reduced when negative performance is obtained;

- for managers, a significant part of the remuneration should be non-fixed and connected with the efficiency of the enterprise, while at least $40 \%$ of the bonus should be deferred for a period of at least 3 years;

- the value of the deferred bonus should increase with the growth of the management position level;

- at least $50 \%$ of the non-fixed bonus must be in the form of shares or other derivatives related to them.

Currently, there are no methods for calculating 
and applying the deferral of bonuses to managers and other employees of the RSI enterprises, who take risks. In this regard, the authors of the present study propose methodological approaches to the calculation and payment of deferred bonuses, depending on the results of production and operation risk management.

At the first stage, it would be most correct to determine significant risks, their indicators, acceptable risk values, on the basis of which the calculation and deferral would be made for employees who accept these risks (Figure 3).

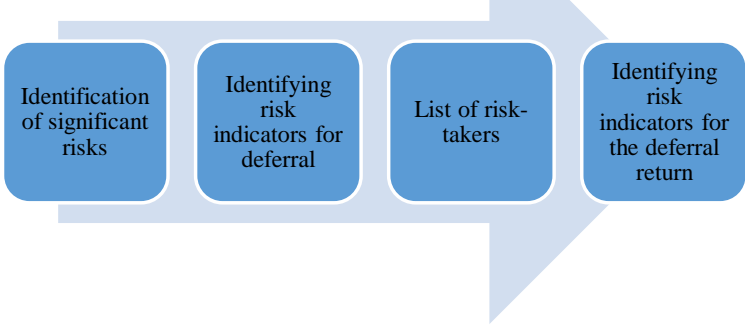

Figure 3. Procedure for deferring the non-fixed part of the remuneration

Source: Compiled by the authors

Risk indicators are determined by the RSI enterprise. Their normative value is set within the framework of the normative value scale $\left(\mathrm{N}_{\max }, \mathrm{N}_{\min }\right)$. If the upper limit is exceeded, the deferred bonus in the amount of $40 \%$ of the total calculated remuneration is not fully paid, and if it is below the minimum normative value $\mathrm{N}_{\min }$, it is paid in full. Within this range, the amount of the returned bonus is determined according to the formula (1):

$$
\mathrm{K}=100 \% \times \frac{1-(\mathrm{Rfact}-N \min )}{N \max -N \min },
$$

where $K-$ the percentage of return of the deferred bonus; $\mathrm{R}_{\text {fact }}-$ the actual value of the risk indicator.
Such a calculation can be very time-consuming; therefore, it is possible to defer the bonus at once for all risk-takers (carrying all types of risks) according to indicators that are uniform for the RSI enterprise.

\section{RESULTS}

In order to calculate the deferred bonus, the level of the materiality of the enterprise's operations for the occurrence of risks that can affect the successful launch and operation of a manned spacecraft is determined.

A deferral (installment plan) and subsequent adjustment of at least $40 \%$ of the bonus to employees who take risks for a period of 3 years is carried out in parts depending on the size of the loan portfolio in such a time-frame as, for example:

- in a year after the reporting period in the amount of $35 \%$ of the deferred part of the bonus;

- in 2 years after the reporting period in the amount of $15 \%$ of the deferred part of the bonus;

- in 3 years after the reporting period, in the amount of $50 \%$ of the deferred part of the bonus.

If a negative for the whole RSI enterprise risk result is obtained, the bonus part extended for the corresponding year may be reduced or canceled.

The calculation of the bonus is carried out in proportion to the amount of time working in the status of an employee taking risks.

The list of key performance indicators for payment/adjustment of deferred bonuses for employees who take risks is established, for example, in accordance with (Table 2) [12].

Table 2. Key indicators for payment/adjustment of deferred bonuses

\begin{tabular}{|c|c|c|c|}
\hline Types of Risks & $\begin{array}{l}\text { Assessment of } \\
\text { the Amount of } \\
\text { Risk by an } \\
\text { Expert* }\end{array}$ & $\begin{array}{c}\text { Risk } \\
\text { Weighting }\end{array}$ & $\begin{array}{c}\text { Risk } \\
\text { Magnitude }\end{array}$ \\
\hline 1. Prototype manufacturing & & 1 & 1.3 \\
\hline Risk of component manufacturing errors & 4 & 0.05 & 0.2 \\
\hline Risk of assembly errors & 2 & 0.1 & 0.2 \\
\hline Risk of lack of material, personnel, time, and other resources & 1 & 0.35 & 0.35 \\
\hline Risks of fulfillment of obligations by counterparties & 1 & 0.25 & 0.25 \\
\hline Risk of work disruption due to unsatisfactory organization of the process & 0 & 0.05 & 0 \\
\hline Risk of poor quality and delivery time of components & 2 & 0,15 & 0.3 \\
\hline External risk for other reasons & 0 & 0.05 & 0 \\
\hline 2. Flight tests & & 1 & 1.65 \\
\hline Test equipment malfunction risk & 1 & 0.1 & 0.1 \\
\hline Risk of errors by test pilots & 2 & 0.1 & 0.2 \\
\hline Risk of resource lack & 2 & 0.6 & 1.2 \\
\hline
\end{tabular}




\begin{tabular}{|c|c|c|c|}
\hline Risk of poor work organization & 0 & 0.05 & 0 \\
\hline Other external risks & 1 & 0.15 & 0.15 \\
\hline 3. Launching rocket and space ships & & 1 & 1.35 \\
\hline Risk of defects & 1 & 0.05 & 0.05 \\
\hline Risk of equipment defectiveness (on the launch pad and at the Mission Control) & 0 & 0.1 & 0 \\
\hline Risk factor group "Human" & 2 & 0.3 & 0.6 \\
\hline Risk factor group "Machine" & 1 & 0.1 & 0.1 \\
\hline Risk factor group "Environment" & 2 & 0.15 & 0.3 \\
\hline Other external risks & 1 & 0.3 & 0.3 \\
\hline
\end{tabular}

${ }^{*}$ Assessment criteria: 0 - an almost impossible event (probability is no more than 0.01 ), 1 - a highly unlikely event (probability is from 0.01 to 0.05 ), 2 - an unlikely event (probability is from 0.05 to 0.10 ), 3 - an event with non-negligible probability (probability is from 0.10 to 0.20 ), $4-\mathrm{a}$ probable enough event (probability is from 0.20 to 0.30 ), 5 - an event with a noticeable probability (probability is more than 0.30 )

Source: Compiled by the authors

The indicators characterizing the manufacture, testing, and launching of a manned spacecraft are used as a risk indicator in the application of deferrals in the payment of bonuses to employees of the RSI enterprises. The maximum terms for deferring the bonus are determined by the deadlines for the manifestation of all risks at these stages, but no more than 3 years.

In this case, the following formulas for calculating the bonus for the payment of the deferred bonus are used (for example, the 2020 bonus) (2-4):

Part of Deferred Bonus 2021

$=$ Performance Bonus for $2020 \times 40 \%$

$\times\left[35 \% \times\right.$ Ktotal $\left._{\text {deferred }_{2021}}\right] \times$ Kcorr,
Part of Deferred Bonus 2022

$=$ Performance Bonus for $2020 \times 40 \%$

$\times\left[15 \% \times\right.$ Ktotal $\left._{\text {deferred }_{2022}}\right] \times$ Kcorr,

Part of Deferred Bonus 2023

$=$ Performance Bonus for $2020 \times 40 \%$

$\times\left[50 \% \times\right.$ Ktotal $\left._{\text {deferred } 2023}\right] \times$ Kcorr,

where Ktotal $_{\text {deferred_i }}$ - the rate of implementation in the $i$ year of the plan for KPIs used to adjust the deferred part of the bonus in accordance with the list of key performance indicators for the payment / adjustment of the deferred bonus for employees who take risks, based on the results of the year.

An example of payment of a deferred bonus to an employee of an enterprise of the RSI is given in Table 3.

Table 3. Example: payment of a deferred bonus to an employee of the RSI, in rubles

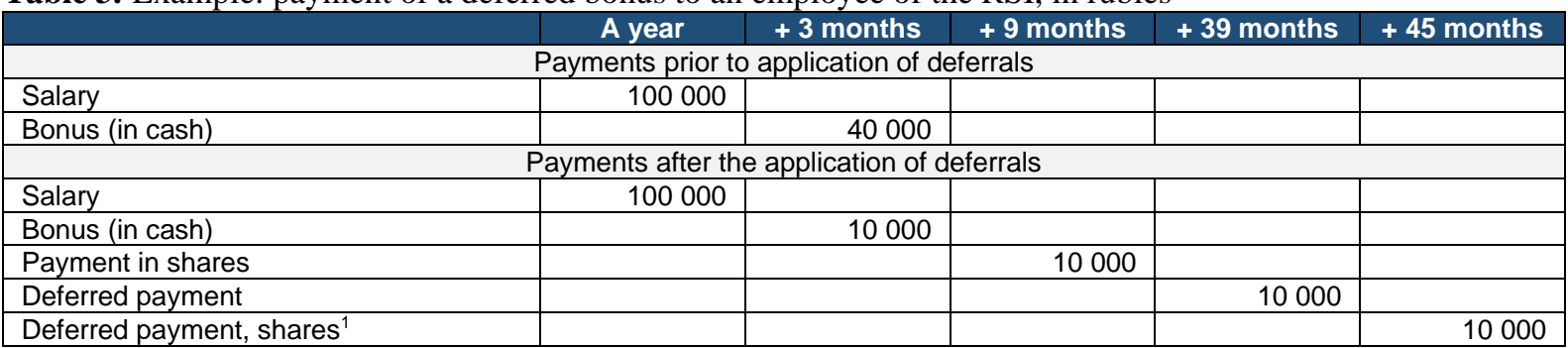

${ }^{1}$ shares can only be used 6 months after their transfer

Source: Compiled by the authors

\section{DISCUSSION}

In recent years, taxpayer organizations are more commonly facing increased attention from the tax authorities regarding the amount of annual bonuses paid to employees (especially those in key management positions), and their accounting as expenses that reduce the income tax base. More and more attention is paid to the correct accounting of bonuses for employees holding managerial positions in an organization when calculating income tax [10].

Considering that various types of bonuses established by organizations independently are included in the salary of an employee by the Labor
Code of the Russian Federation, they can be taken into account in labor costs on the basis of clause 2 of Art. 255 of the Tax Code of the Russian Federation.

However, in order for the amounts of paid annual bonuses to be taken into account as expenses that reduce the corporate income tax base, they must simultaneously meet all of the following criteria [12, 13]:

1) payment of the bonus must be documented, that is, provided for in the labor and/or collective agreement, in other local regulations of the organization, and also formalized by the corresponding order on bonuses; 
2) the employer's expenses for the payment of bonuses must be correctly justified;

3) the bonus should not be paid from funds for other purposes or special-purpose income.

If the compliance with the first and third criteria does not cause practical difficulties, then the interpretation and application of the second criterion raises a number of questions due to the ambiguity of the concept of "justification" of expenses and the possibility of its assessment by tax authorities and courts.

The payment of the annual bonus and its amount must be economically justified, i.e. must be consistent with the financial situation of the organization and the contribution of the employee to be awarded. Therefore, it is necessary to provide justifications for the economic viability of paying annual bonuses in case of questions from the tax authorities (for example, to establish a relationship between financial indicators and the contribution of the employee, to make sure that there is no interdependence of persons who appoint and receive bonuses, etc. [14]).

It is also necessary to prepare documentary evidence of the payment of annual bonuses (for example, to make sure that their regulation, including the criteria for appointing bonuses, is fixed in the labor or collective agreement, in other local regulations; to prepare documents confirming the calculations of bonuses and their relationship with the financial indicators of the employee and the company in general; to formalize the appointment of annual bonuses by the corresponding orders on bonuses).

Long-term bonus plans are of interest to enterprises whose production is associated with the presence of delayed risks of their performance and that create long-term incentive plans aimed at reducing risks.

It is advisable to expand the non-monetary part of bonuses to employees of the enterprise, for example, in the form of options and shares. Thus, Sistema Public Joint Stock Financial Corporation uses a long-term incentive plan based on the use of long-term bonus instruments shown in Figure 4.

Stock Option
- The employee is given the right to acquire in the future a certain number of shares of the employing
company at a price fixed today

Figure 4. Long-term bonus instruments used at Sistema Public Joint Stock Financial Corporation Source: Compiled by the authors

Long-term incentive makes it possible to ensure sustainable growth of the effective work of employees of industrial enterprises in the rocket and space industry for a period of 3-5 years and to ensure a reduction in risks in the process of production and operation of manned spacecraft.

For employees of enterprises, the system will make it possible to increase and maintain the total income in the future 3-5 years.

\section{CONCLUSION}

The novelty of the approach lies in the authors' proposal to use the incentive mechanisms of protection against risks at industrial enterprises of the rocket and space industry that have been tested in the financial sphere, as well as in the authors' adaptation of the principles of calculating and paying the deferred bonus to employees of the RCI enterprises, taking into account the production and operation risks arising at these enterprises.

\section{AUTHORS' CONTRIBUTIONS}

The authors made an equal contribution to the study: collection and analysis of material; definition of goals and objectives, research methods; formulation and scientific substantiation of 
conclusions, registration of key research results in the form of an article.

\section{REFERENCES}

[1] A.S. Slavyanov, E.Yu. Khrustaltev, "Risks and priorities of the strategy of development of the national space-rocket industry", Polythematic Online Scientific Journal of Kuban State Agrarian University, 2017, vol. 129, pp. 10571071. (In Russ.). DOI: 10.21515/1990-4665129-075

[2] V.N. Tovstonoshenko, "Innovation Activities Risks of the rocket and space industry", The Siberian Aerospace Journal, 2015, vol. 16(2), pp. 535-529. (In Russ.).

[3] E.Yu. Khrustalev, A.S. Slavyanov, "The methodology, main principles for setting up the concept for economic protection of space projects and the purpose of the concept", National Interests: Priorities and Security, 2015, vol. 42, pp. 2-9. (In Russ.).

[4] E.Yu. Khrustalev, "Economic security of a knowledge-intensive enterprise: methods of diagnosis and assessment" [Ekonomicheskaya bezopasnost' naukoyemkogo predpriyatiya: metody diagnostiki i otsenki], National Interests: Priorities and Security, 2010, vol. 13(70), pp. 51-58. (In Russ.).

[5] "Basel III: A Global Regulatory Framework for More Resilient Banks and Banking Systems", Basel Committee on Banking Supervision, December 2010 (rev. June 2011). Retrieved from https://www.bis.org/publ/bcbs189.pdf

[6] "Basel III: Long-term Impact on Economic Performance and Fluctuations". BIS Working Papers vol. 338, February 2011. Retrieved from http://www.bis.org/publ/work338.pdf

[7] S.S. Golubev, "Formation of long-term personnel incentive plans" [Formirovaniye dolgosrochnykh sistem motivatsii personala], Banking [Bankovskoye delo], 2014, vol. 9, pp. 59-64. (In Russ.).

[8] "On the regulation of material incentive systems in credit institutions" [O regulirovanii sistem material'nogo stimulirovaniya $\mathrm{v}$ kreditnykh organizatsiyakh], Letter of the Bank of Russia dated 03.09.2009 N 105-T.

[9] S.S. Golubev, S.S. Chebotarev, V.D. Sekerin, A.E. Gorokhova, "Development of employee incentive programmes with regard to risks taken and individual performance", International Journal of Economic Research, 2017, vol. 14(7), pp. 37-46.

[10] "Key Attributes of Effective Resolution Regimes for Financial Institutions”, Financial stability board, 2011. Retrieved from http://www.fsb.org/what-we-do/policydevelopment/effective-resolution-regimes-andpolicies/key-attributes-of-effective-resolutionregimes-for-financial-institutions/

[11] S.S. Golubev, V.I. Volkov, A.G. Shcherbakov, V.D. Sekerin, A.E. Gorokhova. "Manpower Support for Digital Technology Implementation Processes in Industrial Enterprises", International Journal of Engineering and Advanced Technology, 2019, vol. 8(3), pp. 414-420.

[12] A.I. Orlov, A.D. Tsisarskiy, "Features of risk assessment in the development of rocket and space technology" [Osobennosti otsenki riskov pri sozdanii raketno-kosmicheskoy tekhniki], National Interests: Priorities and Security, 2013, vol. 43(232), pp. 37-46. (In Russ.).

[13] "Payment of annual bonuses: trends and practice: development forecasts”, LT In Focus, Tax legislation. Overview Deloitte Tax \& Legal Consulting Department, 26 December 2016. Retrieved from https://www2.deloitte.com/ content/dam/Deloitte/ru/Documents/tax/lt-infocus/russian/2016/26-december.pdf

[14]E. Dyundik, S. Golubev, A. Makhova, L. Gurtskoy, "Development of human capital in the military industrial complex of Russia in the context of digital transformation", in Proceedings of the ISPC "Environmental Risks and Safety in Mechanical Engineering", 2020, vol. 217, p. 06005. DOI: $10.1051 /$ e3sconf/202021706005 